\title{
A cautionary tale about the use of colony- forming efficiency as a proxy for the survival of mesenchymal stem cells
}

\author{
Kim O'Connor ${ }^{1,2}$ (D)
}

\begin{abstract}
Colony-forming efficiency is a time-honored metric of the proliferation potential of mesenchymal stem cells (MSCs). This commentary raises a concern about the practice of using colony-forming efficiency as a proxy for cell survival. A recently published study from my laboratory investigated this issue. A marker of cellular aging, CD264, was employed to separate human bone marrow MSCs into populations of CD264- cells and culture-matched, aging $\mathrm{CD}^{264^{+}}$cells with high and low colony-forming efficiency, respectively. In vitro cell survival was evaluated with a single-cell assay; in vivo survival by bioluminescence imaging of MSCs attached to scaffolds that were implanted ectopically in immunodeficient mice. In our study, in vitro and in vivo survival of the MSC populations was independent of colony-forming efficiency. This finding indicates that caution should be exercised before using colony-forming efficiency as an indirect metric of cell survival. Direct measurement of survival may be required. Awareness of this issue should foster a robust experimental design and, thereby, facilitate the translation of MSC research into clinical practice.
\end{abstract}

Keywords: Colony-forming unit assay, Survival, Mesenchymal stem cells

\section{Background}

The colony-forming unit (CFU) assay is a popular method to assess the proliferation potential of mesenchymal stem cells (MSCs). Friedenstein et al. were the first to discover MSCs by their characteristic ability to form discrete fibroblast colonies [1]. The CFU assay measures the efficiency by which MSCs form colony units when plated at clonogenic levels in monolayer culture on tissue culture plastic. Today, colony-forming efficiency is frequently employed for quality assessment of MSC preparations used in preclinical research and clinical trials $[2,3]$.

Correspondence: koc@tulane.edu

'Department of Chemical and Biomolecular Engineering, School of Science and Engineering, Tulane University, 6823 Saint Charles Ave., Boggs Center Room 300, New Orleans, LA 70118, USA

${ }^{2}$ Center for Stem Cell Research and Regenerative Medicine, School of

Medicine, Tulane University, New Orleans, LA, USA
This commentary raises a concern about the practice of using colony-forming efficiency as an indirect measure of MSC survival. As discussed below, the underlying assumption of equivalence between these two parameters is invalid in some instances. A recently published study from my laboratory provides illustrative examples [4]. In such cases, measurements of colony-forming efficiency can lead to misinterpretation of experimental data and spurious conclusions about MSC survival. Instead, direct measurement of cell survival is warranted. Given the popularity of the CFU assay, its misuse has the potential to slow the translation of MSC research into clinical practice. The goal of highlighting this issue here is to promote rigorous MSC research and, in turn, accelerate the development and manufacturing of MSC therapies.

(c) The Author(s). 2020 Open Access This article is licensed under a Creative Commons Attribution 4.0 International License, which permits use, sharing, adaptation, distribution and reproduction in any medium or format, as long as you give appropriate credit to the original author(s) and the source, provide a link to the Creative Commons licence, and indicate if changes were made. The images or other third party material in this article are included in the article's Creative Commons licence, unless indicated otherwise in a credit line to the material. If material is not included in the article's Creative Commons licence and your intended use is not permitted by statutory regulation or exceeds the permitted use, you will need to obtain permission directly from the copyright holder. To view a copy of this licence, visit http://creativecommons.org/licenses/by/4.0/ The Creative Commons Public Domain Dedication waiver (http://creativecommons.org/publicdomain/zero/1.0/) applies to the data made available in this article, unless otherwise stated in a credit line to the data. 


\section{In vitro and in vivo survival}

Many stem cell scientists recognize that cell survival is only one of several factors that contribute to colony formation [5]. Some researchers, however, employ colony formation as an indirect measure of in vitro cell survival $[6,7]$. This practice of using colony formation as a proxy for survival yields a false-negative result when a cell survives in culture but is unable to proliferate into a colony. In this scenario, colony-forming efficiency underestimates the percentage of surviving cells. Recently, my research group published an illustrative example with human bone marrow MSCs (hBMSCs) [4]. Each culture was separated into two populations by fluorescenceactivated cell sorting based on surface expression of CD264. We previously identified CD264 as a marker of cellular aging whose expression is upregulated in hBMSCs during serial passage and is correlated to elevated levels of senescence-associated $\beta$-galactosidase [8].
Aging CD264 ${ }^{+}$hBMSCs formed colonies less efficiency relative to their $\mathrm{CD} 264^{-}$counterpart, but the two populations had comparable in vitro survival at the single-cell level (Fig. 1a) [4]. Reliance on only colony formation as a metric of survival would have produced false-negative results in this case. The use of a single-cell assay, like the one in our study, is an effective method to evaluate both in vitro survival and colony formation.

Others have suggested that in vitro colony-forming efficiency may be a predictive metric of in vivo MSC survival [9]. Our findings do not support this supposition. In the study described above, we compared the survival of $\mathrm{CD} 264^{+/-}$hBMSCs attached to ceramic scaffolds, which were implanted subcutaneously in immunodeficient mice [4]. Bioluminescence imaging revealed that matched implants of CD264- and CD264 ${ }^{+}$hBMSCs from the same culture had a similar in vivo half-life despite a lower colony-forming efficiency for the aging a

CD264-

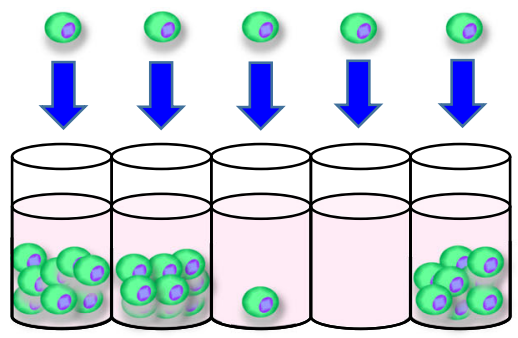

CD264+

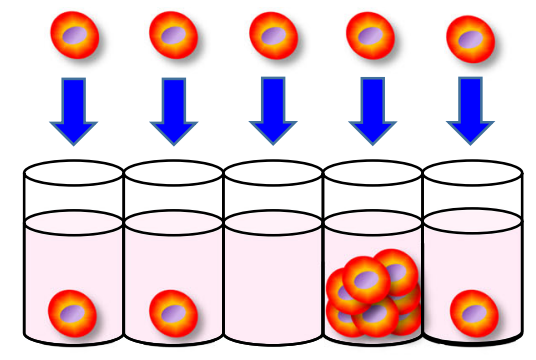

\% Survived (CD264-) = \% Survived (CD264+)

CFU (CD264-) > CFU (CD264+) b

CD264-

CD264+
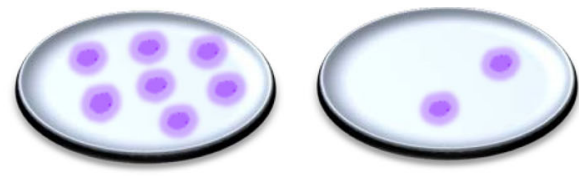

CD264-

CD264+

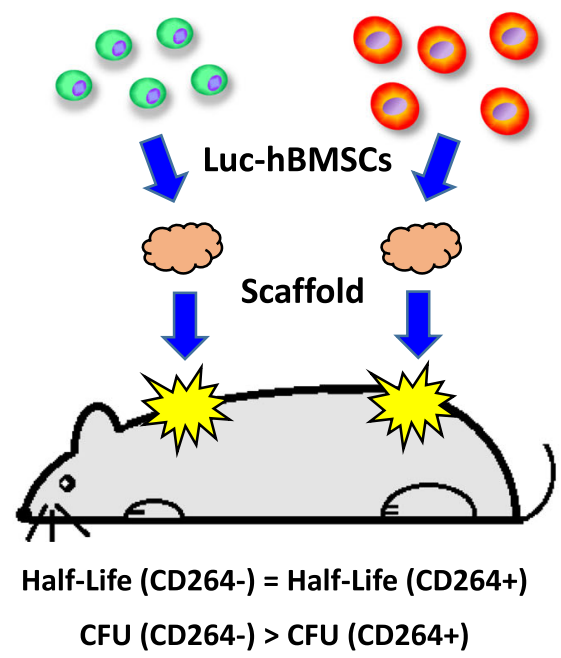

Fig. 1 Illustration of the discrepancy between the colony-forming efficiency and survival of CD264 ${ }^{+/-}$populations of hBMSCs. The two populations were generated by fluorescence-activated cell sorting based on the expression of CD264, a marker of cellular aging. a In vitro survival and colony-forming efficiency was resolved at the single-cell level by inoculating multi-well plates via limiting dilution. In wells inoculated with single cells, culture-matched CD264- and CD264 ${ }^{+}$populations had a comparable percentage of surviving cells after a week of culture, as measured by cell attachment; however, fewer of the aging CD264 ${ }^{+}$cells formed colonies > 10 cells during the same period. $\mathbf{b}$ In vivo survival of the two populations was evaluated by bioluminescence imaging for a month after the cells were implanted subcutaneously on the dorsum of immunodeficient mice. Prior to implantation, hBMSCs were transduced with a luciferase, sorted into CD264 ${ }^{-}$and CD264 ${ }^{+}$populations, and attached to ceramic scaffolds. For each sorted population, colony-forming efficiency was measured 2 weeks after the cells were plated at clonogenic levels into 10-cm culture dishes. The luminescence half-life was similar for culture-matched CD264 ${ }^{-}$and CD264 ${ }^{+}$populations despite a lower efficiency for CD264 $4^{+}$cells to form colonies > 50 cells. CFU, colony-forming unit; hBMSCs, human bone marrow mesenchymal stem cells; Luc, luciferase 
CD264 ${ }^{+}$cells (Fig. 1b) [4]. These findings cast doubt on the utility of colony-forming efficiency as a metric of in vivo survival. Other in vitro assays are needed that have greater predictive value and mimic the stresses that MSC encounter upon implantation [10].

\section{Conclusions}

The CFU assay is an important tool for quality assessment of MSCs in research and biomanufacturing, but there are limits to its use. Caution is warranted when considering colony-forming efficiency as a proxy for the in vitro and in vivo survival of MSCs. Examples were provided where this practice is invalid. Awareness of this problem should promote more robust survival research and expedite its translation into effective MSC therapies.

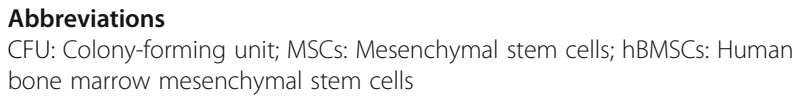

\section{Acknowledgements}

Not applicable

\section{Author's contributions}

The author wrote, read, and approved the final manuscript.

\section{Author's information}

Prof. O'Connor specializes in the biological variability of mesenchymal stem cells and its implication for regenerative medicine. Her honors include the Gaden Award from Biotechnology and Bioengineering and Tulane Health Sciences Award for Leadership and Excellence in Intercampus Collaborative Research.

\section{Funding}

This commentary is based on work supported by the National Science Foundation (CBET-1604129) and the Tulane University Carol Lavin Bernick Faculty Grant Program. Any opinions expressed in this article are those of the author and do not necessarily reflect the views of the National Science Foundation or Tulane University.

\section{Availability of data and materials}

Not applicable

\section{Ethics approval and consent to participate}

Not applicable

\section{Consent for publication}

Not applicable

\section{Competing interests}

The author declares that she has no competing interests.

Received: 14 June 2020 Revised: 28 June 2020

Accepted: 1 July 2020 Published online: 16 July 2020

\section{References}

1. Friedenstein AJ, Chailakhjan RK, Lalykina KS. The development of fibroblast colonies in monolayer cultures of guinea-pig bone marrow and spleen cells. Cell Tissue Kinet. 1970;3:393-403.

2. Chaput CD, Shar A, Jupiter D, Hubert Z, Clough B, Krause U, Gregory CA How stem cell composition in bone marrow aspirate relates to clinical outcomes when used for cervical spine fusion. PLoS One. 2018;13:e0203714.

3. Salamanna F, Contartese D, Giavaresi G, Sicuro L, Barbanti Brodano G, Gasbarrini A, Fini M. A rationale for the use of clotted vertebral bone marrow to aid tissue regeneration following spinal surgery. Sci Rep. 2020;10: 4115 .
4. Madsen SD, Jones SH, Tucker HA, Giler MK, Muller DC, Discher CT, Russell KC, Dobek GL, Sammarco MC, Bunnell BA, O'Connor KC. Survival of aging $\mathrm{CD}_{264^{+}}$and CD264 ${ }^{-}$populations of human bone marrow mesenchymal stem cells is independent of colony-forming efficiency. Biotechnol Bioeng. 2020;117:223-37.

5. Rennerfeldt DA, Raminhos JS, Leff SM, Manning P, Van Vliet KJ. Emergent heterogeneity in putative mesenchymal stem cell colonies: single-cell time lapsed analysis. PLoS One. 2019;14:e0213452.

6. Crowley LC, Christensen ME, Waterhouse NJ. Measuring survival of adherent cells with the colony-forming assay. Cold Spring Harb Protoc. 2016. https:// doi.org/10.1101/pdb.prot087171.

7. Ngo LP, Chan TK, Ge J, Samson LD, Engelward BP. Microcolony size distribution assay enables high-throughput cell survival quantitation. Cell Rep. 2019;26:1668-78.

8. Madsen SD, Russell KC, Tucker HA, Glowacki J, Bunnell BA, O'Connor KC Decoy TRAIL receptor CD264: a cell surface marker of cellular aging for human bone marrow-derived mesenchymal stem cells. Stem Cell Res Ther. 2017;8:201.

9. Giannoni P, Scaglione S, Daga A, llengo C, Cilli M, Quarto R. Short-time survival and engraftment of bone marrow stromal cells in an ectopic model of bone regeneration. Tissue Eng Part A. 2010;16:489-99.

10. Moya A, Paquet J, Deschepper M, Larochette N, Oudina K, Denoeud C, Bensidhoum M, Logeart-Avramoglou D, Petite H. Human mesenchymal stem cell failure to adapt to glucose shortage and rapidly use intracellular energy reserves through glycolysis explains poor cell survival after implantation. Stem Cells. 2018;36:363-76.

\section{Publisher's Note}

Springer Nature remains neutral with regard to jurisdictional claims in published maps and institutional affiliations. 